\title{
Knowledge Levels, Cutlery Management and Number of Germs on Toddler Cutleries
}

\author{
Dyah Suryani $^{1}$, Wibowo ${ }^{2 \text { (corresponding author) }}$
}

${ }^{1}$ Faculty of Public Health, Ahmad Dahlan University Yogyakarta, Indonesia

${ }^{2}$ Research and Development Center for Health Resources and Services, Ministry of Health Indonesia (wibow0869@yahoo.co.id)

Submitted: March 22, 2019 -Revised: April 12, 2019 -Accepted: May 5, 2019 -Published: May 31, 2019

\begin{abstract}
Background: Cleanliness of toddler feeding utensils that have low immune system / susceptibility to the exposure of disease is a very important part and influences the quality of food and drinks. Cutlery sanitation aims to kill vegetative microbial cells left on the surface of the appliance. Washing and cleaning utensils are very important in food processing and inseparable part of the principles of food preservation. The use of cutlery that is determined or determined by the Ministry of Health in 2004 is the total number of tableware germ that is $\leq 100$ colonies $/ \mathrm{cm}^{2}$ from the surface of the equipment being examined. The purpose of this study was to determine the relationship between the level of knowledge and management of eating utensils with the number of germs counts in toddler cutlery in Blawong I Sub-village, Bantul. Methods: The type of this research was analytic observational with laboratory tests and cross-sectional research designs. The sampling technique used in the study was probability sampling. The sample in this study were mothers who have children under five in Blawong I Sub-village, Bantul. The research instrument used was a laboratory test and questionnaire. Data analysis used descriptive and bivariate analysis and the Fisher's Exact Test as an alternative test. Results: There was found the relationship between the level of knowledge with the number of germs in the tableware of Blawong I Bantul sub-village with p-value of 0.011. There was no correlation between the management of tableware with the number of germs counts in Blawong I Bantul Sub-village toddlers' cutlery with p-value of 0.224. Conclusion: There was a relationship between the level of knowledge with the number of tableware germs in Blawong I Bantul sub-village and there was no relationship between the management of tableware with the number of germs on toddler cutlery in Blawong I, Bantul.
\end{abstract}

Keywords: level of knowledge, management of cutlery, number of germs

\section{INTRODUCTION}

Food is one of the basic needs or something which is absolutely necessary in a life, especially humans, in addition to animals and plants. Because without food life cannot be sustained. Therefore, food must be managed properly so as not to experience pollution either caused by microorganisms or certain chemicals. ${ }^{(1)}$ Maintaining food sanitation is an effort to control food, people, places and equipment that can or may cause illness or health problems. Food contamination is caused by various factors. Among others factors, knowledge of food handlers is still low, including healthy behavior, food handlers' body cleanliness, cleanliness of eating utensils and food sanitation. ${ }^{(2)}$ Foodborne illness is considered a public health problem that has arisen throughout the world. The surface of the equipment in contact with food in the processing and presentation process is considered as a major factor in the risk of food contamination. ${ }^{(3)}$ Contamination of food, one of which is caused by the presence of unclean eating utensils will cause disease due to bacterial contamination contained in the food equipment. It can cause a disease known as food and water borne disease, where the entry of food into the body resulting in contamination to body because the food is contaminated by microbes, the presence of these microbes that cause gastrointestinal infections. Using tableware commonly used as a place or container for food is an inseparable part of the principles of food hygiene. Clean cutlery is not a guarantee of meeting health requirements because the cutlery has been contaminated with bacteria that causes the tool these foods do not meet health requirements. $^{(4)}$

Cleanliness of toddler feeding utensils who have low immune system / vulnerable to the arrival of disease is a very important part and influences the quality of food and drinks. Clean washed cutlery can cause organisms or germs left behind to multiply and contaminate the food that will be placed on it. All food utensils that have the opportunity to come into contact with food must always be kept clean and no food residue is left in the cutlery parts. ${ }^{(5)}$ Cutlery sanitation aims to kill vegetative microbial cells left on the surface of the appliance. Washing and cleaning of cutlery is very important to help prevent pollution or contamination of so the process of washing cutlery is very important. Keeping tableware clean means that it has helped to prevent contaminant of food consumed. Clean eating utensils properly, will produce clean and healthy eating utensils and avoid the 
initial causes of health problems or foodborne diseases. The cause of food that often occurs is diarrhea. Diarrheal disease is still a public health problem in Indonesia, both in terms of morbidity and mortality caused. ${ }^{(6)}$ Washing and cleaning utensils are very important in food processing and are an inseparable part of the principles of food preservation. Ignorance of food managers in efforts to clean eating utensils can be a cause of health problems and diseases due to foodborne illness. ${ }^{(7)}$

Blawong 1 sub-village is part of Trimulyo Village, located in Jetis District, Bantul Regency, Yogyakarta. The number of toddlers in Blawong 1 sub-village is quite large at 52 toddlers. The initial observation of 2 toddlers 'parents on the level of knowledge / ignorance of toddlers' parents found their knowledge is still low and it is a problem of the use of cutlery and management of cutlery which is not appropriate to the cleanliness of toddler cutlery. Toddlers who still have a weak immune system are prone to contracting diseases need to be considered to reduce the incidence of the disease caused by germicidal / bacterial contamination that is used in toddler feeding equipment for Blawong 1 Bantul sub-village. Based on the results of preliminary observations made by researchers on May 4, 2016, that cutlery especially toddlers' cutlery (2 plates) in Blawong 1 sub-village Bantul is still found to be inadequate or unclean from bacteriological contamination obtained by germ counts of 6784 colonies $/ \mathrm{cm}^{2}$ and 1590 colonies $/ \mathrm{cm}^{2}$ toddler's cutlery. The use of cutlery that is determined or determined by the Ministry of Health in 2004 is the total number of tableware germ that is $\leq 100 \mathrm{colonies} / \mathrm{cm}^{2}$ from the surface of the equipment being examined. There is still some toddler cutlery that is used contain bacteriological. This proves that the process of washing the cutlery is not good. Based on this, the researchers are interested in conducting research on the relationship between the level of knowledge and management of cutlery with the presence of germ numbers in toddlers' eating places in Blawong 1 Bantul.

\section{METHODS}

This research is analytic observational research with laboratory tests and cross-sectional research designs. Cross-sectional research is a study to study the dynamics of correlation between risk factors and effects, by way of approach, observation or data collection at a time (point time approach). That is, each research subject was only observed once and measurements were made on the character status or subject variables at the time of examination. ${ }^{8}$ The sample in this study were mothers who had toddlers in Blawong I Bantul sub-village with a total of 35 people and samples of cutlery, namely plates used for toddlers' daily feeding containers. The research tool used was a questionnaire level of knowledge about the management of toddler's feeding equipment and behavior of managing toddler's feeding equipment. While measuring the number of cutlery bacteria, using the cutlery method then the sample is taken to the Laboratory. Data analysis used univariate analysis and the bivariate analysis by using the Fisher's Exact Test.

\section{RESULTS}

\section{Characteristics of Respondents} below.

Characteristics of respondents under five mothers in Blawong I Bantul sub-village can be seen in table 1

Table 1. Characteristics of mothers of toddlers in Blawong I sub-village, Bantul

\begin{tabular}{|c|c|c|c|}
\hline Characteristic & Category & Frequency & Percentage (\%) \\
\hline \multirow{4}{*}{ Age } & $20-30$ & 4 & 11.4 \\
\cline { 2 - 4 } & $31-40$ & 23 & 65.7 \\
\cline { 2 - 4 } & $41-50$ & 6 & 17.1 \\
\cline { 2 - 4 } & $51-60$ & 2 & 5.7 \\
\hline Level of & Low & 12 & 34.3 \\
\cline { 2 - 4 } Education & High & 23 & 65.7 \\
\hline \multirow{4}{*}{ Working status } & IRT & 28 & 80.0 \\
\cline { 2 - 4 } & Entrepreneur & 2 & 5.7 \\
\cline { 2 - 4 } & Teacher & 2 & 5.7 \\
\cline { 2 - 4 } & Employee & 1 & 2.9 \\
\cline { 2 - 4 } & Nurse & 1 & 2.9 \\
\cline { 2 - 4 } & Civil Servant & 1 & 2.9 \\
\hline Income level & $<1.000 .000$ IDR & 5 & 85.3 \\
\cline { 2 - 4 } & $\geq 1.000 .000$ IDR & 30 & 85.7 \\
\hline
\end{tabular}


From table 1, it is known that the majority of mothers of children under five years old in Blawong I subvillage, Bantul, aged 31-40 years were 23 people (65.7\%), while those aged 51-60 years were 2 people $(5.7 \%)$. Mother of toddler Blawong sub-village with low education as many as 12 people (34.3\%), while mothers of toddlers who have higher education as many as 23 people $(65.7 \%)$. Occupational mothers of toddlers on average were housewives as many as 28 people $(80.0 \%)$, and the minority of them were employees, nurses, teachers as much as 1 person $(2.9 \%)$. The income level of respondents with less than 1 million was 5 people $(14.3 \%)$, while the income level $\geq 1,000,000$ was 30 people $(85.7 \%)$.

\section{Descriptive Analysis}

The results of the analysis of the level of knowledge and management of cutlery with germ numbers can be seen in table 2 below.

Table 2. Distribution of knowledge level, management of cutlery and the number of cutlery bacteria in Blawong I sub-village

\begin{tabular}{|c|c|c|c|}
\hline Variable & Category & Frequency & Percentage \\
\hline \multirow{2}{*}{ Knowledge } & Not good & 10 & 28.6 \\
\cline { 2 - 4 } & Good & 25 & 71.4 \\
\hline \multirow{2}{*}{$\begin{array}{c}\text { Management of } \\
\text { cutlery }\end{array}$} & Not good & 6 & 17.1 \\
\cline { 2 - 4 } & Good & 29 & 82.9 \\
\hline Number of germs & Not good & 8 & 22.9 \\
\cline { 2 - 4 } & Good & 27 & 77.1 \\
\hline
\end{tabular}

Based on table 2, it can be seen that the majority of respondents had good knowledge about the management of cutlery, by 25 people (71.4\%), while respondents who had bad knowledge were 10 people (28.6\%). Most respondents had good management cutlery, by29 people (82.9\%), while respondents who had poor management of cutlery were 6 people $(17.1 \%)$. From all respondents, 35 samples of cutlery that have good category or qualify, by 27 cutleries $(77.1 \%)$, while those who are not good or do not meet the requirements for germ counts of cutlery were 8 cutlery / plates $(22.9 \%)$.

\section{Bivariate Analysis}

Bivariate results analysis used to find out the relationship between the independent variable and the dependent variable. The statistical test used was the Fisher test. The confidence level used was $95 \%$ and the level of significance of the relationship seen a significant value (p-value $<0.05$ ) and by looking at the value of the Prevalent Ratio (RP).

\section{$\underline{\text { Relationship between Respondent's Knowledge Level and Germ Figures for toddler cutlery }}$}

The results of bivariate analysis between the level of knowledge of respondents with the number of cutlery infants can be seen in table 3 below:

Table 3. Relationship between the level of knowledge of respondents with the number of germs utensils for toddler's cutlery in Blawong I Hamlet

\begin{tabular}{|c|c|c|c|c|c|c|}
\hline \multirow{2}{*}{ Knowledge } & \multicolumn{4}{|c|}{ Number of germs } & \multirow{2}{*}{ p-value } & RP (95\% CI) \\
\cline { 2 - 5 } & \multicolumn{2}{|c|}{ Not good } & & \\
\cline { 2 - 5 } & Frequency & Percentage & Frequency & Percentage & & \multirow{2}{*}{ Good } \\
\hline Not good & 6 & 17.14 & 6 & 17.14 & 6.011 & $(1.362-24.271)$ \\
\hline Good & 2 & 5.72 & 21 & 60 & \\
\hline Total & 8 & 22.86 & 27 & 77.14 & & \\
\hline
\end{tabular}

Based on the results of the analysis using the Fisher exact test, $\mathrm{p}$ value $=0.011$ was obtained with a value of $\mathrm{p}<0.05$, which means that there was a relationship between knowledge and the number of tableware germs in the Blawong I sub-village, Bantul. Prevalence Ratio $(\mathrm{RP})=5.750(95 \%=1.362-24.271)$ which shows that bad 
knowledge will affect the number of tableware germs by 5.750 times greater than the cutlery with good knowledge, then the results can be stated that this research is statistically and biologically meaningful.

\section{Relationship Between Management of Respondents' Feeding Utensils and the Number of Germs.}

The results of the bivariate analysis between respondent's cutlery management behavior with toddler cutlery numbers can be seen in table 4 below:

Table 4. The relationship between respondent's tableware management behavior with the number of infants in the Blawong I sub-village

\begin{tabular}{|c|c|c|c|c|c|}
\hline \multirow{2}{*}{$\begin{array}{c}\text { Management } \\
\text { of cutlery }\end{array}$} & \multicolumn{3}{|c|}{ Number of germs } & \multirow{2}{*}{ p-value } \\
\cline { 2 - 5 } & Frequency & Percentage & Frequency & Percentage & \\
\cline { 2 - 5 } & 6 & 17.14 & 13 & 37.14 & \multirow{2}{*}{0.224} \\
\hline Not good & 2 & 5.72 & 14 & 40 & \\
\hline Good & 8 & 22.86 & 27 & 77.14 & \\
\hline Total & \multicolumn{3}{|c|}{ Not good } & \\
\hline
\end{tabular}

Based on the results of the analysis using the fisher exact test, $p$-value $=0.224$ was obtained with $p$-value of $<0.05$ which means that there was no relationship between the behavior of tableware management with the number of germs on the toddler cutlery of Blawong I Bantul sub-village. These results indicate that the management of tableware has no relationship between management with germ numbers both statistically and biologically.

\section{DISCUSSION}

\section{The Relationship Between Level of Knowledge and the Number of Germs in Blawong I Sub-village Toddler's Cutlery}

The results of this study stated that there was a relationship between mother's knowledge about the management of cutlery with the number of toddler's cutlery utensils in the Blawong I sub-village, Bantul, with $\mathrm{p}$-value $=0.011$ and Prevalence Ratio $(\mathrm{RP})=5.750(95 \%=1,362-24,271)$. This is consistent with the theory which states that most human knowledge is obtained through the eyes and ears. Knowledge itself is influenced by formal education factors. Knowledge is very closely related to education, where it is expected that with higher education the person will also be more knowledgeable. It needs to be emphasized that this does not mean that a person with low education must also have low knowledge. ${ }^{(8)}$ Increased knowledge is not absolutely obtained from formal education but can be obtained from through non-formal education. A person's knowledge of an object contains two positive aspects and a negative aspect. These two aspects will determine a person's attitude. The more positive aspects and objects that are known, the more positive attitude will be imposed on certain objects. Health objects can be described through one form of knowledge gained from experience alone. ${ }^{(9)}$ Hygiene practices and sanitation management are important parts of food contamination prevention programs. Although the majority of food processors have the skills and knowledge to handle food safely, errors in handling food are the cause of most food poisoning outbreaks. ${ }^{(10)}$ This study is consistent with previous research which suggests that inadequate food safety knowledge and skills from food handlers can result in unsafe food handling practices and cross contamination in food service areas. ${ }^{(1)}$ A study shows that food vendors play a big role in food contamination. The low level of knowledge about food safety can be caused by the low level of education of food vendors. ${ }^{(12)}$

\section{The Relationship Between Management of Tableware with the Number of Germs in Blawong I Sub- village Toddler Cutlery}

In this study, the value of $p$ value $=0.224$ was obtained with a value of $p<0.05$ which means that there was no relationship between the management of eating utensils with the number of germs on the toddler cutlery of Blawong I sub-village, Bantul. This states that the number of germs in a toddler's cutlery is not affected by the management of tableware. One possible reason is the basic ingredients of the plate that are not controlled in this study. Plates made of plastic and melamine, it is more difficult to remove oil and grease from the surface of the 
plates compared to plates made of glass. This is in accordance with previous research which states that plate equipment that uses plastic and melamine as a base does have special care. This is due to the difficulty of removing certain odors, fats, or oils that stick to the dish washing equipment even though we have washed it repeatedly, we can use lime juice or dishwashing soap that contains the aroma of orange or lemon. ${ }^{(13)}$ The water used for washing dishes also greatly affects the number of germs on toddler's cutlery. If the water used comes from a source of water that is not safe / contaminated with coliform, it will affect the number of germs in the toddler's cutlery. Previous research states that the quality of water used for washing or in the post-sanitation rinsing process is an important element for maintaining the safety of fresh vegetables especially when more restaurants now rely on buying water from unknown sources. ${ }^{(14)}$ Research conducted in Jambi stated that other factors that caused the number of colonies on plates used by traders were poor even though their dishwashing techniques were good, because of direct factors such as air, water used for washing dishes, and the local environment. ${ }^{(15)}$ Equipment factor such as cutlery is one of the factors that plays an important role in disease transmission, because cutlery that is unclean and contains microorganisms can transmit disease through food. Furthermore, the washing process of cutlery with the application of appropriate washing methods is very important in the effort to reduce the number of numbers germs especially on cutlery. One of the factors that can affect the number of cutlery germs is how to store open cutlery. Bacteria or germs in the air will be mixed with dust, then dust mixed with bacteria will stick to the open tableware. and there are still some respondents doing drying using a cloth to dry the cutlery there are $54.28 \%$ management of cutlery is not good.

Storage of equipment is intended to avoid contamination of tableware before use. Cutlery that has been washed and dried can be directly stored in a tool cabinet that is protected from dust and closed and easy to reach when used. Storage cabinets are placed away from sources of pollutants and do not allow pollution in the process of transporting cutlery to be ready for use in serving food. This is intended to prevent food contamination by the equipment used. ${ }^{(6)}$

\section{CONCLUSION}

\section{Conclusion}

Based on the results of the study and discussion of the research described earlier, it can be concluded that there is a relationship between the level of knowledge with the number of germicidal tableware in Blawong I sub-village, Bantul. There was no relationship between the management of tableware with the number of germs on the toddler cutlery of Blawong I Bantul.

\section{Suggestion}

For Jetis Bantul Community Health Center can provide counseling to mothers of children under five and empower health cadres, especially for residents of Blawong I Bantul to be able to improve knowledge and how to manage tableware (toddlers) properly and correctly.

\section{REFERENCES}

1. Mastra N, Merta IW. Observation on the number of germs wiping cutlery at Renon Tattwamasi Orphanage Denpasar 9 (Observasi Angka Kuman Usap Alat Makan di Panti Asuhan Tattwamasi Renon Denpasar). Jurnal Skala Husada. 2010:8(2).

2. Rombot, Hadiansyah MI, Maramis FRR. Description of Escherichia Coli Germs and Bacteria in Tableware Restaurants in Manado City Pinasungkulan Market (Gambaran Angka Kuman dan Bakteri Escherichia coli pada Peralatan Makan Rumah Makan di Pasar Pinasungkulan Kota Manado). Jurnal Kesehatan Masyarakat Universitas Sam Ratulangi Manado. 2014.

3. Faille C, Cunault C, Dubois T, Bénézech T. Hygienic design of food processing lines to mitigate the risk of bacterial food contamination with respect to environmental concerns. Innovative Food Science and Emerging Technologies. 2018:46;65-73

4. Bobihu F. Study of Sanitation and Examination of Germs Rate at Smoked Tableware at Central Market Complex of Gorontalo City (Studi Sanitasi dan Pemeriksaan Angka Kuman Pada Usapan Peralatan Makan Di Rumah Makan Kompleks Pasar Sentral Kota Gorontalo). Jurnal Kesehatan Masyarakat Fakultas Ilmuilmu Kesehatan dan Keolahragaan, Universitas Negeri Gorontalo. 2012. 
5. Tumelap JH. Bacteriological Condition of Tableware at Jombang Tikala Manado Restaurant (Kondisi Bakteriologik Peralatan Makan di Rumah Makan Jombang Tikala Manado). Jurnal Kesehatan Lingkungan. 2012:1(1);22-27.

6. Ministry of Health of Republic of Indonesia. Collection of Food \& Beverage Sanitation Hygiene Course Modules (Kumpulan Modul Kursus Higiene Sanitasi Makanan \& Minuman). Jakarta: Ministry of Health of Republic of Indonesia; 2004.

7. Ministry of Health of Republic of Indonesia. Regulation of Minister of Health Indonesia concerning Jasaboga Sanitary Hygiene (Higiene Sanitasi Jasaboga). Jakarta: Ministry of Health of Republic of Indonesia; 2011.

8. Notoatmodjo S. Public Health and Art (Kesehatan Masyarakat dan Seni). Jakarta: Rineka Cipta; 2007.

9. Dewi M, Wawan A. Theory \& Measurement of Human Knowledge, Attitudes, and Behavior (Teori \& Pengukuran Pengetahuan, Sikap, dan Perilaku Manusia). Yogyakarta: Nuha Medika; 2011.

10. Greig JD, Todd EC, Bartleson CA, Michaels BS. Outbreaks where food workers have been implicated in spread of foodborne disease, part 1. Description of the problem, methods, and agents involved. Journal of Food Protection. 2007; 70:1752-1761.

11. McGill CR, Fulgoni VL, Devareddy L. Ten-year fiber and whole grain intakes and food sources for the United States Population: National health and nutrition examination survey 2001-2010. Nutrients. 2015:7;1119-1130.

12. Sani NA, Siow ON. Knowledge, attitudes and practices of food handlers on food safety in food service operations at the Universiti Kebangsaan Malaysia. Food Control. 2014:37;210-217.

13. Supriadi EC. The Number of Germs in Cutlery at SDN Canteen No.47 Telanaipura Jambi City (Angka Kuman Pada Alat Makan di Kantin SDN No.47 Telanaipura Kota Jambi). Jurnal Ilmiah Universitas Batanghari Jambi. 2018;19(2);432-437.

14. Faour-Klingbeil, Kuri V, Todd E. Microbiological quality of ready-to-eat fresh vegetables and their link to food safety environment and handling practices in restaurants. Food Science and Technology. 2016;74:224-233.

15. Marisdayana R, Sahara P, Yosefin H. Washing Equipment for Cutlery, Personal Hygiene Against Bacterial Contamination of Cutlery (Teknik Pencucian Alat Makan, Personal Hygiene Terhadap Kontaminasi Bakteri pada Alat Makan). Jurnal Endurance. 2017:2(3);376-382. 